\title{
Upaya Peningkatan Kemampuan Mengenal Angka melalui Media Audio Visual Pada Siswa Tunagrahita SLB N Angkola Timur
}

\author{
Nuryaningsih \\ Kepala Sekolah SLB N Angkola Timur \\ email: nuryaningsih564@gmail.com
}

Received: 13 August 2021; Revised: 02 October 2021; Accepted: 28 December 2021

DOI: http://dx.doi.org/10.37905/aksara.8.1.649-654.2022

\begin{abstract}
Belajar adalah proses membangun pengetahuan seseorang melalui kegiatan. Salah satu proses membangun pengetahuan adalah berhitung. Anak tunagrahita adalah anak yang memiliki kelainan mental dan memiliki tingkat kecerdasan dibawah rata-rata serta memiliki kemampuan intelektual lemah dibandingkan dengan anak lainnya. Sehingga memerlukan suatu media pembelajaran yang sesuai sebagai upaya peningkatan pengetahuan berhitungnya. Salah satu media yang dapat digunakan adalah media audio dan visual atau media video. Banyaknya media audio visual yang dapat diakses saat ini, sangat membantu kegiatan belajar mengajar bagi anak-anak tunagrahita. Penelitian ini menggunakan pendekatan kuantitatif terhadap 7 responden anak-anak tunagrahita di SLB N Angkola Timur dengan melibatkan guru pengajarnya. Responden diambil secara acak, dengan perbandingan responden yang digunakan adalah $57.1 \%$ responden yang sudah mengenal angka dan $42.9 \%$ responden belum mengenal angka. Hasilnya seluruh responden sangat tertarik melihat video pembelajaran mengenal angka. Serta terjadi kenaikan yang signifikan terhadap responden. Adapun indikator keberhasilan dilihat dari kecepatan menyebutkan angka, kemampuan menyebut angka dan kemampuan mengingat angka.
\end{abstract}

Kata kunci: Tunagrahita, Video, Kemampuan mengenal angka

\section{PENDAHULUAN}

Perkembangan teknologi saat ini, menjadikan salah satu media sebagai pendukung segala kegiatan dan aktifitastermasuk kegiatan belajar mengajar. Media pembelajaran berbasis audio visual merupakan salah satu media yang dianggap mampu mendukung kegiatan belajar mengajar saat ini (Wahyuni, 2021). Dengan dilengkapi gambar bergerak dan suara menjadikan video pembelajaran ini mampu membantu siswa dalam meningkatkan kemampuan belajar berhitung. Terutama dalam belajar berhitung dan pengenalan bilangan. Belajar adalah proses membangun pengetahuan seseorang melalui kegiatan(Saputra \& Febriyanto, 2019). Proses konstruksi ini dilakukan melalui banyak sumber disekitar baik dari alam maupun sumber lainnya. Anak tunagrahita adalah anak yang memiliki kelainan mental dan memiliki tingkat kecerdasan dibawah rata-rata serta memiliki kemampuan intelektual lemah dibandingkan dengan anak lainnya. Sehingga kegiatannya perlu dibantu dan dipantau oleh orang disekitarnya termasuk dala belajar berhitung (Manshur \& Ramdlani, 2020). 
Berhitung adalah kegiatan dalam menyebutkan urutan bilangan. Kegiatan berhitung diawali dengan menyebutkan angka 1-20 pada anak usia dini secara normal (Malapata \& Wijayanigsih, 2019). Tetapi pada anak tunagrahita, berhitung merupakan kegiatan yang perlu dibantu dan dipandu hingga anak benar-benar mengerti angka dan mampu berhitung sendiri (Kuswandi \& Kuswandi, 2017). Berdasarkan hal tersebut, maka anak tunagrahita memerlukan suatu media pembelajaran yang sesuai sebagai upaya peningkatan pengetahuan berhitungnya. Banyak media berhitung yang dapat digunakan oleh anak tunagrahita antara lain, behitung mengunakan kartu. Media kartu digunakan untuk anak tunagrahita kategori sedang. Media kartu merupakan media visual yang berisi simbol-simbol sehingga dalam melakukan komunikasi verbal. Penelitian yang dilakukan oleh Purnomo, Shodiq dan Samawi (2019) menyatakan bahwa pembelajaran berhitung untuk anak tunagrahita kategori sedang menggunakan media kartu memiliki tingkat keberhasilan sedang. Hal ini ditunjukkan dengan hasil uji terhadap 6 siswa tunagrahita, kenaikan kemampuan berhitungnya masih perlu diperbaiki(Purnomo, Shodiq AM, \& Samawi, 2019). Media kegiatan berhitung lain adalah menggunakan tangga untuk anak tunagrahita kategori sedang, dan hasilnya terdapat peningkatan kemampuan berhitung anak. Tetapi penggunaan tangga hitung cepat membuat anak bosan dan tidak mau mengikuti pelajaran berhitung (Maulidiyah, Sudarsini, \& Sunandar, 2020).

Berdasarkan uraian diatas, penulis menggunakan media lain yaitu berupa media audio visual guna mendukung kegiatan belajar berhitung dan mengenal angka untuk anak tunagrahita di SLB N Angkola Timur.

\section{METODE PENELITIAN}

Penelitian ini dilakukan dengan pendekatan kuantitatif pada anak tunagrahita di SLB N Angkola Timur. Pengambilan sampel dilakukan dengan menggunaan random sampling terhadap 7 siswa secara acak di SLB N Angkola Timur. Adapun alat pengambilan data dengan menggunakan kuesioner yang diisi oleh 7 guru SLB $\mathrm{N}$ Angkola Timur, dengan alat pengolah data menggunakan software opensource.

Penelitian tindakan kelas ini dilakukan sebagai upaya dalam meningkatkan kemampuan anak tunagrahita di SLB N Angkola Timur. Adapun langkah-langkah tindakan kelas yang dilakukan adalah:

1. Para guru memutar video pengenalan angka 1-5 untuk siswa di SLB N Angkola Timur. Video ini di tayangkan secara berulang yaitu 3-4 kali selama pelajaran berhitung dan anak diajak melihat video tersebut sambil menirukan dan menyebutkan angka yang tertera pada video tersebut.

2. Selanjutnya, guru memutar kembali video tersebut dan meminta anak untuk menyebutkan angka yang ada di video tersebut.

3. Guru melakukan pengamatan dan menilai anak-anak, apakah ada peningkatan dalam menyebutkan angka.

4. Guru menilai kemampuan anak dalam menghafal angka 1-5. 
Adapun langkah-langkah penelitian disajikan pada Gambar 1. Dibawah ini.

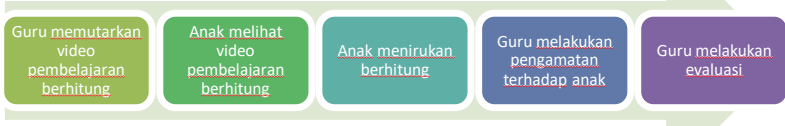

Gambar 1. Langkah-langkah penelitian

\section{PEMBAHASAN}

Pada tahap pertama, guru memutarkan video pembelajaran berhitung untuk anakanak, dan anak-anak sangat tertarik melihat video pembelajaran. Video pembelajaran ini diujikan kepada anak tunagrahita secara acak, baik yang belum mengenal angka maupun yang sudah mengenal angka. Dengan prosentase 3 anak belum mengenal angka dan 4 anak sudah mengenal angka. Adapun data ditunjukkan pada Gambar 2.

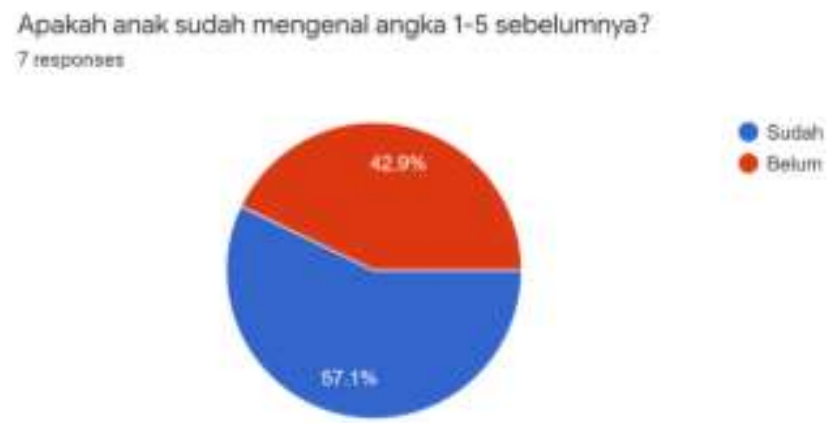

Gambar 2. Perbandingan anak yang mengenal angka 1-5 dan yang belum mengenal angka

Gambar 2 menunjukkan prosentase perbandingan audience yaitu jumlah anak yang sudah mengenal angka dan yang belum mengenal angka. Anak yang mengenal angka sebayak $57.1 \%$ dan yang belum mengenal $42.9 \%$. data ini nantinya akan digunakan untuk menguji kemampuan anak dalam menghitung angka 1-5 setelah melihat video pembelajaran. Seluruh anak-anak akan diajak melihat video pembelajaran dan diuji apakah anak tertarik atau tidak, dan hasilnya seluruh anak tertarik melihat video pembelajaran. Hal ini disajikan pada Gambar 3 berikut.

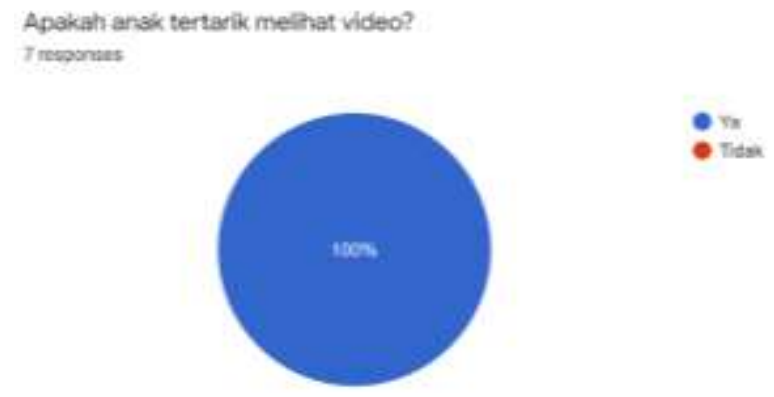

Gambar 3. Hasil survey ketertarikan anak melihat video pembelajaran 
Berdasarkan Gambar 2 diatas, menunjukkan hasil survey terhadap responden, bahwa anak sangat tertarik melihat video pembelajaran berhitung. Hal ini disebabkan media pembelajaran audio visual sangat menarik bagi anak-anak tunagrahita karena berisi teks, gambar, suara dan musik.

Tahap kedua adalah anak-anak menirukan angka yang disebutkan dalam video pembelajaran dan hasilnya adalah anak-anak mampu menirukan. Tetapi video diputar lebih dari satu kali. Hal ini disajikan pada Gambar 3.

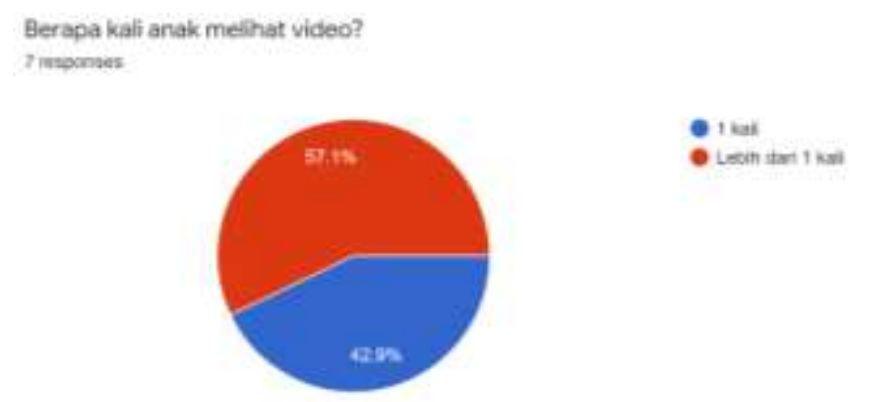

Gambar 3. Hasil survey frekuensi melihat video pembelajaran

Gambar 3 menjelaskan bahwa, rata-rata frekuensi pemutaran video pembelajaran dilakukan lebih dari 1 kali. Sebanyak 57\% responden atau kurang lebih 4 guru memutar video pembelajaran lebih dari 1 kali. Harapannya anak akan lebih sering melihat video sehingga mampu untuk mengingat dan menirukan angka 1-5.

Tahap ketiga adalah guru melakukan pengamatan terhadap kemampuan anakanak dan hasilnya disajikan pada Tabel 1 berikut.

Tabel 1. Tabel hasil pengamatan kemampuan anak

\begin{tabular}{ccc}
\hline Nama Anak & $\begin{array}{c}\text { Kenaikan } \\
\text { kemampuan } \\
\text { (Ya/Tidak) }\end{array}$ & $\begin{array}{c}\text { Pengenalan angka } \\
\text { sebelum melihat video } \\
\text { (Sudah/Belum) }\end{array}$ \\
\hline Anak 1 & Ya & Sudah \\
Anak 2 & Ya & Sudah \\
Anak 3 & Ya & Sudah \\
Anak 4 & Ya & Sudah \\
Anak 5 & Ya & Belum \\
Anak 6 & Ya & Belum \\
Anak 7 & Ya & Belum \\
\hline
\end{tabular}

Berdasarkan Tabel 1, maka rata-rata kemampuan anak untuk mengenal angka 1-5 mengalami kenaikan. Kenaikan ini dilihat dari beberapa hal antara lain:

a. Untuk anak yang sudah mengenal angka sebelumnya, terdapat beberapa perbedaan yaitu:

1. Kemampuan menirukan penyebutan angka lebih cepat dari biasanya

2. Kemampuan mengingat angka lebih signifikan

3. Lebih tertarik untuk menyebutkan angka ketika diputarkan video. 
b. Untuk anak yang belum mengenal angka sebelumnya, perbedaannya adalah:

1. Mampu menirukan angka tanpa dibimbing

2. Mampu mengingat angka dengan dibimbing

Hal ini memberikan hasil lebih baik dibandingkan sebelum menggunakan video pembelajaran mengenal angka.

\section{KESIMPULAN}

Berdasarkan uraian diatas maka kesimpulan penelitian ini adalah, adanya kenaikan signifikan pada anak tunagrahita dalam mengenal angka 1-5. Kenaikan signifikan ini dialami oleh seluruh anak yang diamati. Baik yang mengenal angka sebelumnya maupun yang sudah mengenal angka sebelumnya yaitu sebanyak 57.1\% dari total audien. Kenaikan bagi anak yang semula sudah mengenal angka, lebih cepat merespon ketika melihat video pembelajaran pengenalan angka. Sedangkan bagi anak yang belum mengenal angka 1-5 sebelumnya yaitu $42.9 \%$ dari total audien, ada kenaikan kemampuan dalam menyebutkan angka, meskipun masih dibimbing oleh guru. Tetapi secara kemampuan lebih cepat menyebutkan dibandingkan sebelum melihat video pembelajaran. Kedepan, penelitian ini akan dikembangkan dengan mengkombinasi peran orang tua wali atau sejenisnya demi peningkatan kemampuan akademis anak-anak tunagrahita pada SLB N Angkola Timur.

\section{DAFTAR PUSTAKA}

Kuswandi, I., \& Kuswandi, I. (2017). Upaya Guru Dalam Meningkatkan Motivasi Belajar Siswa Tunagrahita Dengan Mengoptimalkan Penggunaan Media Yang Ada Pendahuluan Pendidikan merupakan suatu hal yang sangat penting bagi manusia . Melalui pendidikan , manusia dapat membina kepribadian dan menge. 1(2), 30-42.

Malapata, E., \& Wijayanigsih, L. (2019). Meningkatkan Kemampuan Berhitung Anak Usia 4-5 Tahun melalui Media Lumbung Hitung. Jurnal Obsesi : Jurnal Pendidikan Anak Usia Dini, 3(1), 283. https://doi.org/10.31004/obsesi.v3i1.183

Manshur, U., \& Ramdlani, M. (2020). Media Audio Visual Dalam Pembelajaran Pai. Al Murabbi, 5(1), 1-8. https://doi.org/10.35891/amb.v5i1.1854

Maulidiyah, N. K., Sudarsini, S., \& ... (2020). Operasi Hitung Sederhana dengan Media Tangga Pintar Anak Tunagrahita. Jurnal ..., 5(November), 96-99.

Purnomo, D. D., Shodiq AM, M., \& Samawi, A. (2019). Pengaruh Media Dot CardsTerhadap Kemampuan Berhitung Siswa Tunagrahita Sedang. Jurnal ORTOPEDAGOGIA, 5(1), 1-5. https://doi.org/10.17977/um031v4i12018p001

Saputra, V. H., \& Febriyanto, E. (2019). Media Pembelajaran Berbasis Multimedia Untuk Anak Tuna Grahita. ... : Jurnal Pendidikan Matematika, 1(1), 15-23. Retrieved from https://ejurnal.teknokrat.ac.id/index.php/jurnalmathema/article/view/350

Wahyuni, S. N. (2021). Pengembangan Game Edukasi Untuk Anak Usia Dini Berbasis Mobile Menggunakan Construct 2. Jurnal Sisfokom (Sistem Informasi Dan Komputer), 10(2), 264-269. https://doi.org/10.32736/sisfokom.v10i2.1140 
AKSARA: Jurnal Ilmu Pendidikan Nonformal

P-ISSN 2407-8018 E-ISSN 2721-7310 DOI prefix $\underline{10.37905}$

Volume 08, (1), January 2022

http://ejurnal.pps.ung.ac.id/index.php/Aksara

654 AKSARA: Jurnal Ilmu Pendidikan Nonformal 